\title{
no words for angels: reading Irigaray without you
}

\author{
Kath MacLean
}

Cette pièce de critique fiction explore en profondeur les textes de Luce Irigaray pour mettre au jour une histoire de la narratrice qui évoque son dialogue avec les pronoms personnels qu'elle utilise à des fins littéraires. Le je met l'invisible en mots, le il inscrit ce texte sur un palimpseste, qui donne une texture à la division $d u$ il en tu, autour du elle et vice-versa. Le texte porte sur la perte et l'absence, mais aussi sur l'accumulation de souvenirs matérialisés. En essayant de préserver la mémoire du toucher, la narratrice se replonge dans des moments isolés, examinant ses sens à tous les niveaux. Finalement, elle ne peut pas oublier parce qu'elle ne peut pas cesser d'attendre, de recommencer, de refuser, de comprendre.

\& the angels would circulate as mediators of that which has not yet happened, of what is still going to happen, of what is on the horizon.

\section{- Irigaray, This Sex Which is Not One}

On the horizon of a story is found what was in the beginning. ${ }^{1}$ in the beginning as i remember it the horizon moves, a picture i make in my head just yesterday when i see him in the middle of a group of young men \& women he tries to break the rhythm of their slow step, with his elbows he pushes at corners i impose with this frame. his hot breath burns holes in the surface as if he's taken a cigarette \& held it down too long in one spot. now, all that's left is a perfect black circle over his face so i can't show you him later in the living room where i tell you this story.

On the horizon of a story is found what was in the beginning ...

i could describe him. i could tell you his corduroy jacket spreads out behind him, covers the screen just as if this were a movie. his. a moving picture he wants to stop. to reach a conclusion, a beginning. i stare into the camera, cover the lens with my hands afraid of being seen or seeing what i'm not supposed to. faster than i can follow his dark figure down the mall the flutter of feather \& wings above. the noise of the espresso maker, steam rising as quickly as these words i speak. his footsteps echo quick \& light, a softness like something falling. if you weren't listening 
you could miss them.

i can tell you this now. in the dark telling is easy. you can't see my eyes, can't take the image i must describe this to you in my own way: the language shaping itself, unshaping itself with the touch of my hand in yours, my fingertips caress your lips, almost as if i want you to tell me, transfer the words. this is our story; it unfolds under our skin as we touch something is born.

he holds the strap of his knapsack in his left hand \& drapes it across his shoulder. his right hand is a closed fist he breaks the space-time around him a spider's web. the patterns glisten in the light for a moment before the tearing, before the silver threads fall to the ground his hand touching the circles within the web. inside the web i think of the repetition of waiting, spinning around the centre, not moving any further away then this.

in the right light, when the sun spills from the windows above, he walks into another space. not here, but where i can't follow. [An] angel is that which unceasingly passes through the envelope(s) or container(s), goes from one side to the other, reworking every deadline, changing every decision, thwarting all repetition (15). i want to tell you here, in the living room, over \& over: look into this space, but it's only the candle flickering, the hands of the clock move when i remember this story, already the ocean takes you. she opens her mouth \& you accept. you never turn to look behind where $i^{\prime} m$ alone in the prairie the seasons change. the year is a thought between my thighs, a warm memory. touch moves, too far away to reach back for you \& your lips speak another story. seagulls, salt in the air, an unfamiliar wind blows through you. here, there is red wine on the carpet. something solid to remember.

from behind the counter of a cafe i sip a cappuccino, read the newspaper. there are ink stains on my finger tips, notes up \& down the surface of a Styrofoam cup. my song. the song i might have sung to you once, before, yesterday, today. if you were here beside me now, you'd hear the lyrics. music behind words i haven't spoken. words in the touch of my hand.

his footsteps might be the drumming, a familiar rhythm that won't go away. the slippery hypnotic sound his jacket makes, vinyl rubbing against cloth when he moves his arms. he breathes quickly. his chest rises \& falls, deflates, becomes flat. as he passes before the window the sky 
flexes its hand, its fingers stretch to touch him with sunlight. the rhythm: it is loud inside. inside where $\mathrm{i}$ continue singing. to sing. to you, are you listening?

the moment i reclaim myself, the world shrinks. i can hardly see me in it. in you. in the mirror of your eyes words curl up inside \& wait for the burning, cigarettes, sunlight or moon?

turn off the light \& wait for words. you force me to look beyond the body. to speak of what i can't see. what is beyond touch. outside the window a veil of frozen stars. when we kiss the glass together the coldness of our lips speak of what is to come: winter grows in my belly, the soles of my feet tear as $i$ climb over the edges of stars $i$ chase the moon wanting to remember its texture. wanting it between my hands, mine.

no one is there when $\mathrm{i}$ answer the door. $\mathrm{i}$ slide the locks back into place. down the hallway the scent of wet leaves, rain, the loud crying of birds that comes before a storm. when you are not here, under the cloak of morning, he follows me down the hall. when i return in the afternoon he is still here, following. just footsteps away creating distance between us enough to remind me of his presence. creating distance through a mastery that constitutes the object as a monument built in place of the subject's disappearance (215).

i disappear into walls, my body presses itself flat, black, into this other place where i can't speak your language.

you don't see him, but you believe, don't you, believe in me?

事必

knowing he looks for you, for me, for some sort of connection between us frightens you. you want to talk about it. don't talk \& maybe it goes away. like the door is quiet tonight. from the balcony where i stand, my palms press against the rails, my face in the background of the city. just then, just now, $i$ am one with the city, listening to it breathe, the horizon rising \& falling rhythmically, when i see him slip from beneath the shadows of the streetlight. then the night falls against my face a piece of velvet cloth, cool \& soft. beneath it the sky is naked. i can't see city lights, a hundred eyes watching. eyes in his feathers burning through wing. through bone, through my eye trying to reach inside where i keep everything i've ever seen. secrets i can't tell you, not even you whom i give everything to just now, for today. when you tire of me, my eyes empty. there will be nothing to look at in the mirror. nothing but a black hole, 
where my eyes used to be, ash, soft \& grey to touch.

my face in the reflection of the chrome counters at the coffee shop. i hardly recognize her. all eyes, blue sky, ocean, beautiful, still. a statue $i^{\prime}$ ve seen somewhere before but i can't remember. she watches him. i stand here waiting, watching her watch him, his reflection watching me. when he is behind me my bracelets become wind chimes, spin around my wrist. for a moment $i$ travel back to the hillsides of Crete, the wind pushing me, a hand against my back propelling me up the cliff until my body moves up the hill as if it isn't mine at all. you won't follow \& as i move away you become smaller \& smaller. i hardly see you. i am nothing more than a small dot in the sky above you, ash \& rock, a fragment of something larger. from the top of the cliff the ocean isn't far away. i can touch it with fingertips \& toes. touch the edges. i could dive into ocean without looking, without thinking of giving. as i touch you now i remember the words $i$ want to tell you. the beginning. all of it.

when i close my eyes waves lap against the shoreline. one on top of the other wrestling with the beach, finding the waves that landed before, finding now when i move towards him in the cafe his body moving, his hand slides the door of a refrigerator open beside the counter, reaches inside \& takes out a slice of banana loaf. his fingers touch the plastic wrap as they might later stroke a cheek. already i see him as he unwraps the loaf, tears pieces with his fingers. when he is about to put some loaf into his mouth, \& his hand is almost to his lips, the wind around us stops. distance closes, the tension of a storm breaks. my blouse clings beneath the arms \& breasts, wet, my body wanting.

he turns towards me to ask if the loaf is good \& $i$ think $i$ assure him $i$ 've had it before, although i don't remember answering. for a moment $i$ can't think of anything except the dislocation of my body from she, from the statue standing waiting for his words when they should be mine. my eyes follow him as he leans against the counter palms facing upwards he waits for his change. hands smaller than $i$ imagined. fingers spread like starfish. (i used to think these were fallen stars in the light you could see wishes shining on the surface like small beads). around his smallest finger he wears an opal ring. inside the opal colours shine as they swim around its gold frame. $i$ think of reds \& greens \& streaks of white trying to escape the dark. they move quickly, so that following them my eyes begin to water. out of focus when i look at his face, his lips ask questions 
i can't read what they're saying. i pull away into the safe spot $i$ hold inside until i feel him distant in another space.

in the hallway beneath the shadows of the moon i see him from my balcony. again. always. with my thumb nail i scrape the frost from the window \& show you his eye watching us. you will think it is a star, some light reflecting from the building across the street. Not holding back, but dwelling in that which wraps itself around a nonforgetfulness (215).

i fold into your body you let me in. reborn, again and again, around a memory of the flesh. ... this impossible memory (215). later, much later, i will break with you, my skin splitting down the centre spilling itself out over the carpet. over the stains we've made celebrating the moon. the notebook our bodies make over the carpet. our language. the song we piece together note by note. a symphony waiting to be discovered.

$* * *$

Touch makes it possible to wait, to gather strength, so that the other will return to caress and reshape, from within and from without, a flesh that is given back to itself in the gesture of love (187).

how do i preserve the memory of you, your touch?

perhaps this is the beginning, reshaping the story, the telling of it. $\mathrm{i}$ watch as he spills coffee on the floor before pouring milk into his mug. ( $\&$ i thought angels were perfect.) i was trying to remember to ask a question. to ask what he wants, but instead i talk about the sudden change in the weather, ask what he does \& before he answers his voice changes. his face in the mirror of the countertop, behind his ring, safe in his dark, he looks at me, his eyes wide not blinking, not even for a moment.

on some deeper level $\mathrm{i}$ know $\mathrm{i}$ wait for him. all this time $\mathrm{i}$ have waited. $i$ have been waiting for a sign to

begin.

perhaps it is the dream: black notes on a Styrofoam cup, coffee, banana loaf. his hand on a clean white counter. lean in closer, the camera pans \& $i$ realize nothing is real. the surface is wet, a moving portrait. in between brush strokes, the tail of a corduroy jacket breaks from the skin of canvas. long brown hair spreads through the dream: a horse's tail in the wind riding

\& riding to sleep. That which ... has taken place, but has no language. The felt, which expresses itself for the first time. Declares itself to the other in silence (215). 
i wake coughing, sucking air into my lungs. my mouth presses into the pillow. i haven't said a word.

all week long $i$ look for signs of him, some invasion. naked before the bathroom mirror $i$ examine my body. hold each limb in my hands as if $i^{\prime} m$ seeing it for the first time. i turn over my right arm \& in the white underside a burn spreads across the width of my flesh, ugly, red. when the skin falls off his thumb print still presses against flesh. afraid it will burn the bone. he makes holes in me, spaces he can fit in/to.

$$
* * *
$$

Saturday afternoon i'm carrying so many bags of groceries in my hands the handles loop around my wrist \& fingers turn purple, then white. when i drop the bags onto the kitchen table the handles are sticky. beneath the thumbnail, flesh opens itself up like an eye. i spill over the bag's plastic handles, i drip down the sides over the tabletop. touch, touching, stains on the surface.

colour changes: an absence of light to red. i hold a glass in my bloodied hand. it slides against my fingers \& palm \& falls to the floor where it smashes by the door of the refrigerator. drop by drop on the marble floor i'm hypnotized by the slow rhythm, me, she, spilling over the floor. i want to count the drops, trace their outlines, but the drops join each other, their shapes disappear \& counting is impossible.

the time it takes to stop bleeding. i hold a cloth to my hand \& apply pressure, but the cloth is soon soaked with blood. i reach for a kitchen towel \& wrap my hand in it as if it were a Christmas gift i give to myself. This is truly a strange I. It takes place both outside and inside the game, but in a radical hemorrhage of herself. She is faraway when she bleeds. ${ }^{2}$

later, the room seeps in colours. fragments of glass slice through me under the skin of my feet, the pain shoots up my legs. as i walk into his picture, this dream $i$ have dancing over the carpet, blood makes noise. each wounding separation, I would answer by refusing. . silently affirming, for myself and for the other, that the most intimate perception of the flesh escapes every sacrificial substitution, every assimilation into discourse, ever surrender to the God... (217)

$* * *$

in another time i could tell you the sun spreads itself out across the sky, the first time this spring. north of the river i watch the sun reflect off office buildings, seductively open itself up, unfolds its dark. in the bath- 
room mirror i look to find the blue-eyed statue smiling, instead there are feathers, wet leaves. someone knocking at the door.

when the moon is full $\mathrm{i}$ feel him growing inside holding my bones between his hands, biting down, hard. in the morning vomit blood into the toilet. my tongue turns white. i peel layers of dead skin from my tongue, make it pink again. in silence my words grow thin, transparent.

in the end, in the beginning, i dream to you. my other, you [c]annot be transformed in to discourse, fantasies, or dreams. It is impossible for me to substitute any other, thing or god, for the other - because of this touching of and by him, which my body remembers (216).

the man with the opal ring, with the corduroy jacket, breaks down the locks \& finds you here sleeping beside me. in a moment the three of us slip behind the mirror in the bathroom, between the spaces where time is real \& moving, to another where life stands still. as we step through this curtain i look straight at the camera, eyes that aren't mine anymore.

in the morning check the pillows for angel wreaths. $i$ find a feather inside the pillow case.

in the beginning the horizon stretches before us prairie mile after mile of seasons. promises we couldn't keep beneath the moon, beneath the frozen night sky where i am always naked. i can't keep from telling you $i$ 've no words for angels, blood on the carpet sings louder than touch $\mathcal{E}$ the statue breaks in the mirror piece by piece until the eyes are ocean $\&$ wind $\mathcal{E} i$ touch you through a blanket of wet leaves. my body remembers dancing over the carpet.

One must remember this and hope that the other remembers. Lodge it in a memory that serves as its bed and its nest, while waiting for the other to understand (215).

\section{Notes}

${ }^{1}$ Luce Irigaray, An Ethics of Sexual Difference (Ithaca: Cornell UP, 1983) 185 . Hereafter all references from this book are referred to by page number.

${ }^{2}$ Luce Irigaray, Sexes and Genealogies (New York: Columbia UP, 1993) 27. 